Article

\title{
Ground-Penetrating Radar Survey for the Study of the Church of Saint Cosma in Helerito (Tagliacozzo, L'Aquila, Italy)
}

\author{
Marilena Cozzolino*(D), Elisa Di Giovanni, Vincenzo Gentile, Paolo Mauriello and \\ Natascia Pizzano \\ Department of Human, Social and Educational Science, University of Molise, Via De Sanctis, \\ 86100 Campobasso, Italy; digiovannielisa@gmail.com (E.D.G.); vincenzo.gentile86@gmail.com (V.G.); \\ mauriello@unimol.it (P.M.); natasciapizzano@gmail.com (N.P.) \\ * Correspondence: marilena.cozzolino@unimol.it (M.C.)
}

Received: 25 May 2020; Accepted: 22 June 2020; Published: 23 June 2020

check for updates

\begin{abstract}
This paper deals with the application of geophysical prospections to the study of the Church of Saint Cosma in Helerito inside the Monastery of Saints Cosma and Damiano (Tagliacozzo, L'Aquila, Italy). The research aimed to verify the presence of buried ancient archaeological structures of a construction phase older than the current building. Thus, a grid of ground-penetrating radar (GPR) profiles was carried out inside the building in the available spaces using a radar unit equipped with a multi-frequency antenna of 200-600 MHz. The analysis of 2D radargrams and horizontal slices relative to different temporal ranges led to the identification of significant regular patterns of the amplitude of the electromagnetic signals. The results suggest the presence of a buried structure below the analyzed surface.
\end{abstract}

Keywords: GPR; archaeological prospections; Church of Saint Cosma in Helerito; chapel of Saint Cosma in Sylvis

\section{Introduction}

Geophysical surveys are largely applied in archaeological prospections [1,2]. In planning the investigations, general preliminary considerations must necessarily be made in collaboration with archaeologists about the characteristics of the targets of the investigations, such as the type of objects to be researched, the supposed constituent material, the hypothesized geometry, the probable dimensions, and the presumed location depth. A technical and scientific analysis must be added to this evaluation considering the type of surface on which to operate, the spacing of the areas to be investigated, the type of terrain, the environmental noise in the area to be studied, the principles and the applicability of geophysical methods to use. In this regard, many techniques are suitable for archaeological explorations.

The geoelectrical method, although having slower acquisition times and small invasiveness due to the need to insert electrodes into the surfaces/terrains compared with other methods, is ideal for identifying deep targets providing easily interpretable results in different soils and surfaces conditions. Many examples prove the efficiency of the method for the detection of near-surface archaeological structures, tombstones, and complex buried buildings [3-12].

Induced electromagnetic methods are very suitable for the identification of high conductivity objects present at depth and have the advantage of being quick to perform, given the lack of electrodes or wires to be placed on the ground. The limitation of these methodologies consists of the low resolution of returning images and the sensibility to metallic objects and humidity that can inhibit the delineation of the buried target. Given the speed with which the survey is conducted, the method is used above others to obtain large-scale information on the territory being analyzed [13-16]. 
Magnetic prospecting is suitable in uniform ground, made of fine materials, and with a moderate magnetic susceptibility. Less favorable conditions for this prospection are sandy soils, surface irregularities, the presence of blocks of volcanic material, or a shallow irregular rocky bedrock. Furthermore, the extreme sensitivity of the magnetic method to metals is a limitation that, in the presence of anthropic structures, influences the quality of data and makes the interpretation difficult. However, the method is useful for identifying shallow objects and structures of archaeological origin, such as furnaces, thermal buildings, and brick walls, in which the material used has been subjected to very high temperatures. In favorable conditions, the magnetic method is very suitable above others in the study of large areas for an overview of archaeological sites [17-21].

The ground-penetrating radar (GPR) method provides high-resolution maps but has limited penetration, which, in the case of high conductivity rocks, such as clays, is reduced. It is very useful in the study of historic buildings [22-28] and in the circumstance in which there is the need to work on paved surfaces [29-31]: In these contexts, it is the least invasive methodology. In good rural conditions, on regular and flat surfaces without high vegetation, the method is also effective, as proved by many papers available in the current literature [32-38].

This paper deals with geophysical prospections realized inside the Church of Saint Cosma in Helerito inside the Monastery of Saints Cosma and Damiano (Tagliacozzo, L'Aquila, Italy). The research aimed to add cognitive elements about the construction phases of the building and to understand the presence of architectural elements still buried in the subsoil, such as the location of the original Church of Saint Cosma in Sylvis of which there are no material traces despite documentary sources which lead to hypothesize its presence in the area of or below the modern structure. Furthermore, as the place of culture is unknown to the community as it is not accessible to the public now, it seemed useful to show the results of this investigation campaign as adding an enrichment of the state-of-the-art of it.

The ground-penetrating radar (GPR) survey was here preferred to other geophysical methods due to the need to operate in a closed room with considerable environmental noise, on a paved surface, and in a narrow space in which to work, limiting the use of induced electromagnetic methods, geoelectrics, and magnetometry. Furthermore, a high-resolution was required to imagine the supposed shallow buried structures in a non-destructive way.

The results yielded important information not available before about the presence of masonry elements in the subsoil. Consequently, the conditions to deepen the studies were created, providing the necessary data to guide direct archaeological investigations in a targeted and precise manner.

\section{Test Site, Material, and Methods}

\subsection{Test Site}

The city of Tagliacozzo is located in central Italy in the province of L'Aquila (Abruzzo region, Italy) (Figure 1a,b). It is located on a carbonate substrate of the Cretaceous-Miocene period (calcarenites, marly limestones, and marls) covered by high-Miocene terrigenous units (marls with silts and sandstones) and volcanic deposits [39]. 

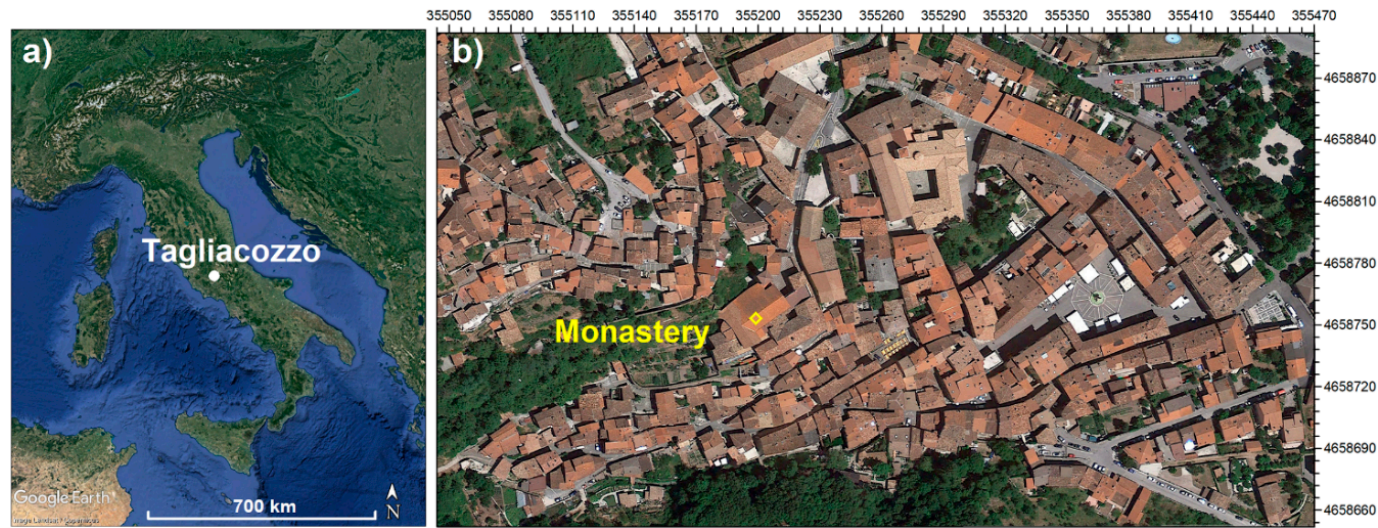

\section{c) Monastery of Saints Cosma and Damiano}

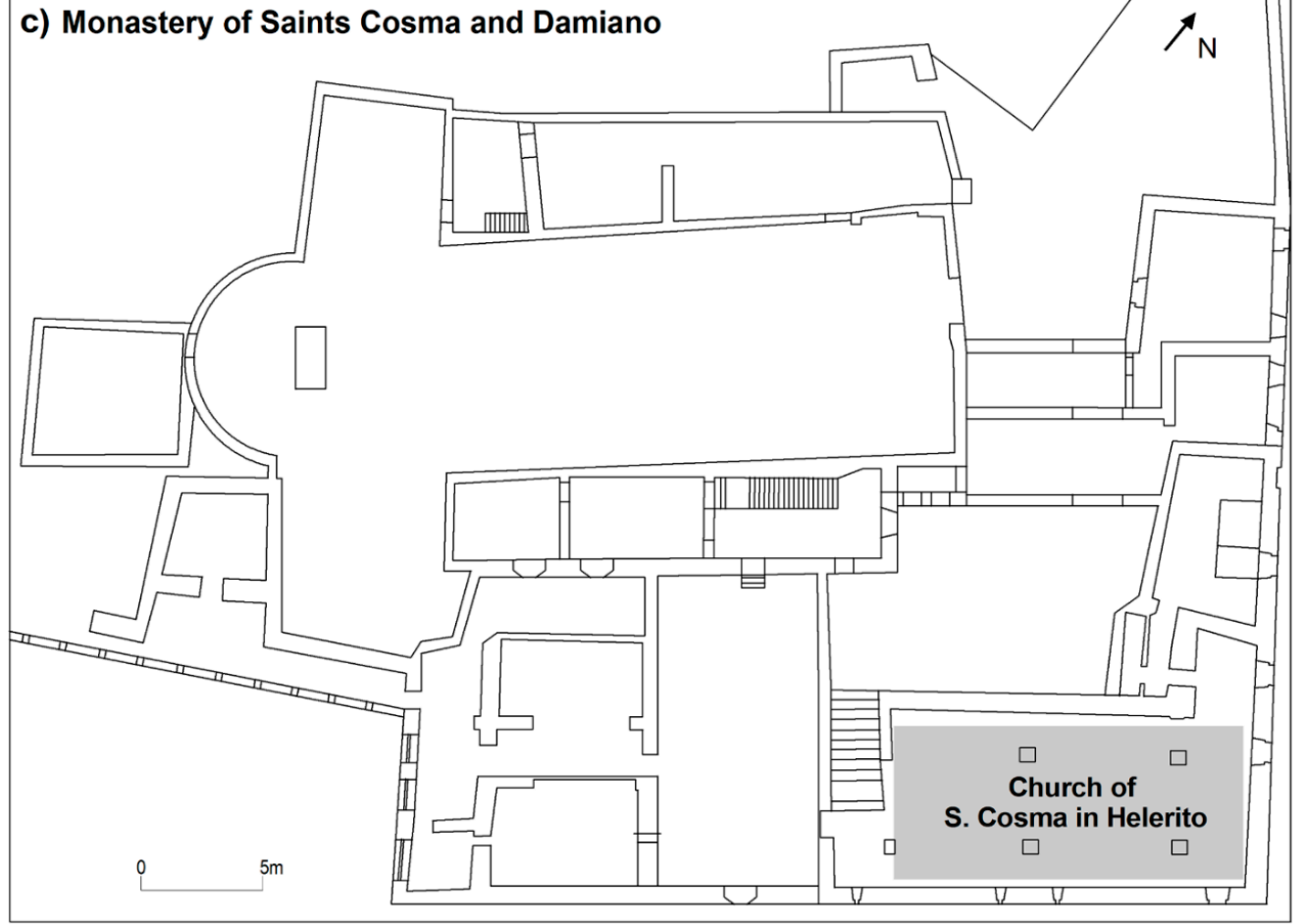

Figure 1. Location of Tagliacozzo (L'Aquila, Italy) (a) and the Monastery of Saints Cosma and Damiano (b) on a Google Earth ${ }^{\mathrm{TM}}$ satellite image and an indication of the Church of Saint Cosma in Helerito inside the planimetry of the monastery (c).

The ancient town probably originated around a small early medieval (VI-IX centuries A.D.) village that circumscribed the convent of Saints Cosma and Damiano, a nucleus that until the XII century had developed in the upstream part of the same monastery. It is placed along the upper part of the Via Tiburtina Valeria, an ancient road that joined Rome to Pescara on the Adriatic coast. Together with the aforementioned monastery, the churches of Saint Pietro, Saint Egidio, Saint Nicola, and Saint Cecilia were also mentioned in a bull of Clement III of 1188 [39]. In fact, the ancient village had to include at that time both the settlement on Mount Civita (or Civitella) and that on Via Valeria: Just down the road, where the Valeria gate opened, the walls enveloped the Monastery of Saints Cosma and Damiano (Figures 1c and 2).

Over time, the center of Tagliacozzo and the near Carsoli became the two most important centers in the whole area. In the Chronicon monasterii casinensis, both the ecclesiam sancti Cosme de Civitella and sancti Angeli in Carzolo are mentioned [40]. Both monasteries could be much older, in particular, according to Gattola, the origins of the Monastery of Saints Cosma and Damiano date back to a Basilian cell of the 5th century A.D., which arose as a shelter for travelers [41]. Recently, the scholar A. Guerra 
has argued that this hypothesis could be confirmed by the discovery of the three capitals of the 5th century A.D. preserved in the Monastery and the Church of Saints Cosma and Damiano, elements of reuse perhaps coming from the original cell $[39,42]$.

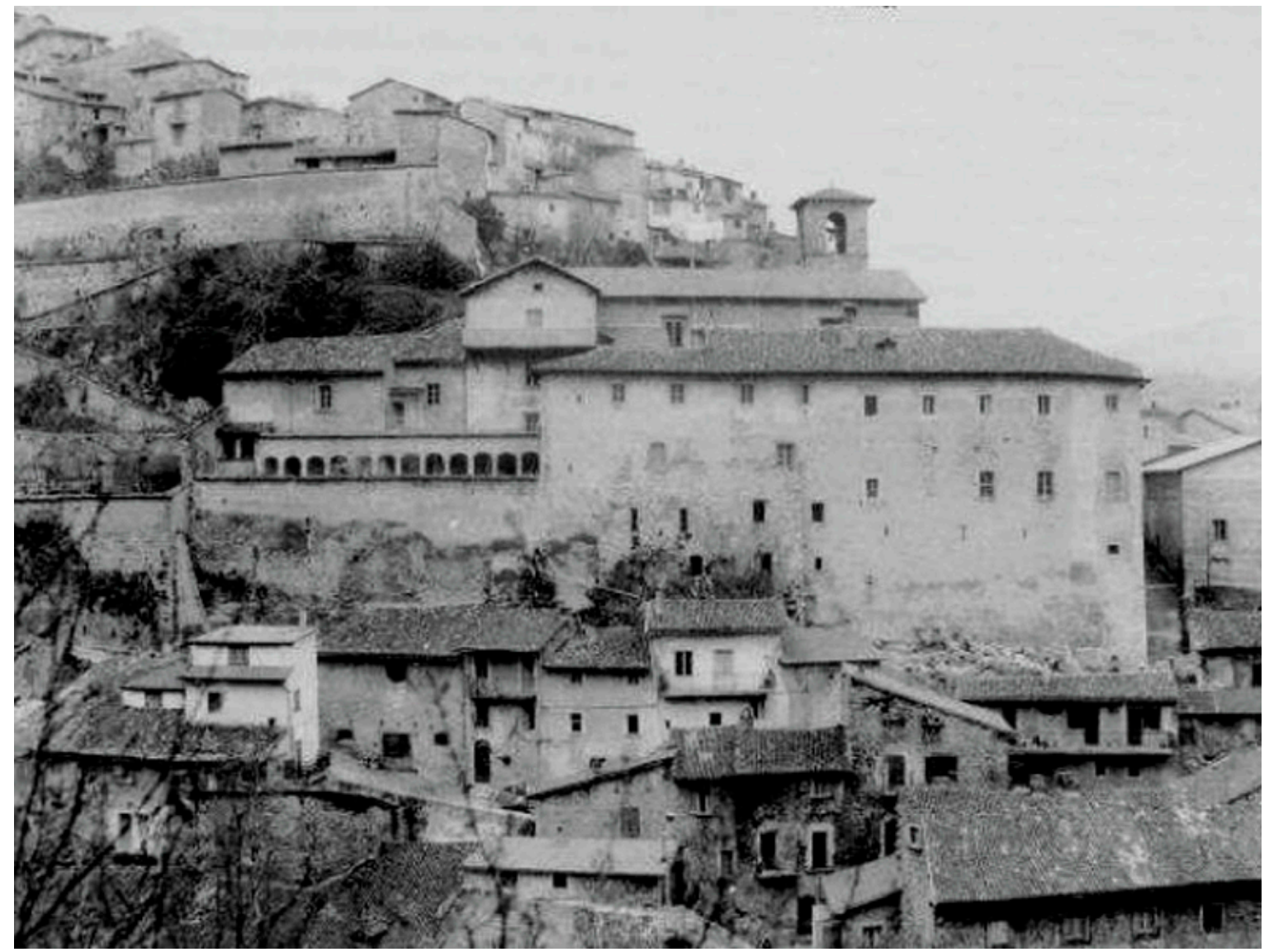

Figure 2. Southern side of the Monastery of Saints Cosma and Damiano $[39,43]$ in a photo dating back to the 1940s.

The Church of Saints Cosma e Damiano is, therefore, one of the most ancient religious architecture of Tagliacozzo: Incorporated in a monastic complex of Benedictine origin, built near a small chapel called Saint Cosma in Sylvis, it has undergone strong changes over the course of the centuries. It is plausible that the ancient church was smaller than the current one, but its location remains uncertain: It could be both the current church, now totally altered in respect to the past, and an older church of which there are clear traces inside the Benedictine monastery, in the lower levels. The church has undergone many and such modifications over the centuries as to make the definition of its construction phases with documented security extremely difficult.

The current scheme is characterized by a Latin cross plan, although the left side of the transept is now incorporated into the monastery (Figure 1c). Recent investigations have shown that the medieval layout of the church had an opposite orientation compared to the current building of worship, rebuilt in the fifteenth century by the Orsini family. The facade originally faced the upper town, where the town was located, while the countryside began behind it. The construction of the new residence of the Orsini moved the city center towards the valley, consequently causing the overturning of the nearby church $[39,42]$. 


\subsection{Materials and Methods}

A GPR survey implies the use of radar units equipped with transmitter-receiver antennas characterized by different frequencies to emit electromagnetic signals into the soils and surfaces. Depending on the properties of materials and on the presence of buried targets, the radar pulse can be attenuated, diffused, dissipated, or reflected towards the surface. The reflection times are relatable with the travel speed with which the wave propagates in the materials.

Taking into consideration the presumed size of hypothesized buried structures, the probable distances between adjacent targets, the size and the logistics of the survey area, a GPR survey was carried out at the Monastery of Saints Cosma e Damiano, inside the little Church of Saint Cosma in Helerito (Figure 1c), using an IDS Georadar (IDS GeoRadar s.r.1., Pisa, Italy), equipped with a multi-frequency TRMF (Time-Reversal Matched Filter) antenna (200-600 MHz).

A plan of profiles was defined inside the naves of the small church, acquiring 35 transversal transects (1-35 in Figure 3) and 10 longitudinal transects (36-45 in Figure 3) with respect to the major side of the building. Where there were no obstacles and enough spaces, lines were spaced $0.5 \mathrm{~m}$ apart to have a dense data grid with a high horizontal resolution avoiding the use of interpolation to fill data gaps.
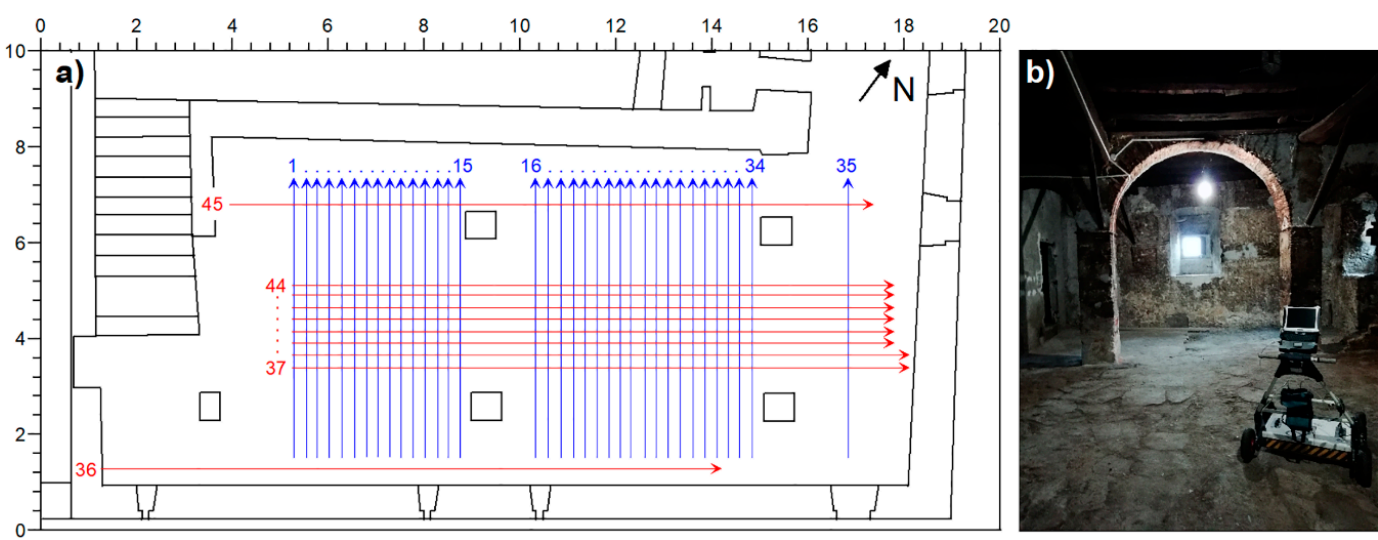

Figure 3. Survey plan showing profiles position (a) and IDS Georadar during data acquisition (b).

Data on each line were acquired as 16-bit data, using 512 samples per trace in a time window of $100 \mathrm{~ns}$. The interval distance between consecutive traces in data acquisition was $2.4 \mathrm{~cm}$, and the scan time was equal to $0.00384 \mathrm{~s}$. As the radar unit implementation allows using the frequency of $200 \mathrm{MHz}, 600 \mathrm{MHz}$, and a crosspolar modality simultaneously (Frequency-Transmitter $200 \mathrm{MHz}$, Frequency-Receiver $600 \mathrm{MHz}$ ), a first evaluation was done considering the results for each of the three acquisitions. As an example, in Figure 4, the radargrams relative to the three gathered data for profile 1 are displayed. In each image, the same anomalies are recognizable, but in the radargram relative to the frequency of $600 \mathrm{MHz}$, there is the clearest representation of them and of the background in which they are immersed. Thus, for further processing, only the data relating to this frequency were subsequently considered.
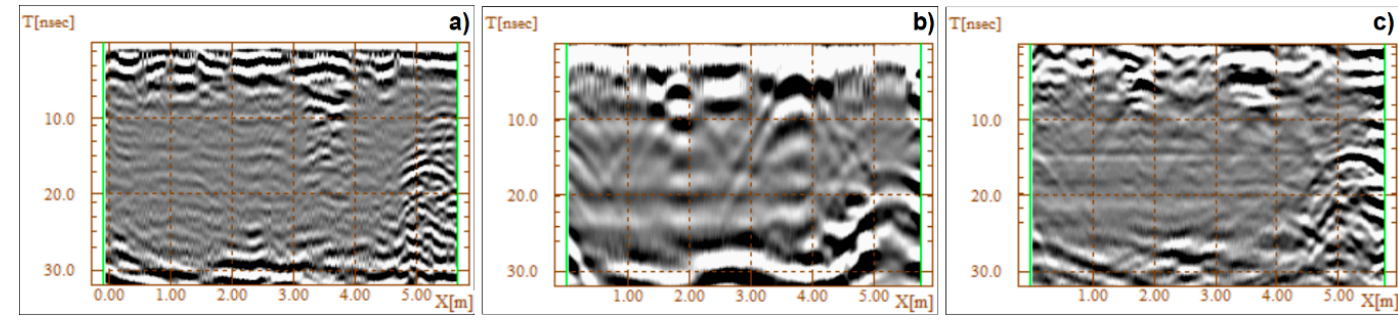

Figure 4. Profile 1: radargram relative to the frequencies of $600 \mathrm{MHz}(\mathbf{a}), 200 \mathrm{MHz}(\mathbf{b})$, and in a cross-polar modality (Freq-Transmitter $200 \mathrm{MHz}$, Freq-Receiver $600 \mathrm{MHz}$ ) (c). 
Data elaboration was carried out using the IdsGred [44] and GPR-SLICE version 7.0 software [45], using the following standard techniques [46,47]: data editing and conversion, dc-drift removal via bandpass filtering, time-zero correction (starting point of the wave (20 samples) and the center frequency of $633 \mathrm{MHz}$ ), background removal in the frequency domain (low cutoff: $72 \mathrm{MHz}$; upper cutoff: 1212 $\mathrm{MHz}$ ), and automatic gaining. Considering the complex layering and the reduced length of the profiles, we preferred not to apply the migration filter, and we avoided presenting results converting time to depth using a mean value with the possibility of obtaining an arbitrary and inaccurate estimate. To provide an idea of the depths of investigation, an average velocity of about $0.1 \mathrm{~m} / \mathrm{ns}$ was matched fitting D, G, and $\mathrm{K}$ hyperbolas in Figure 5, giving a depth scale that ranges between 0 and $1.5 \mathrm{~m}$.
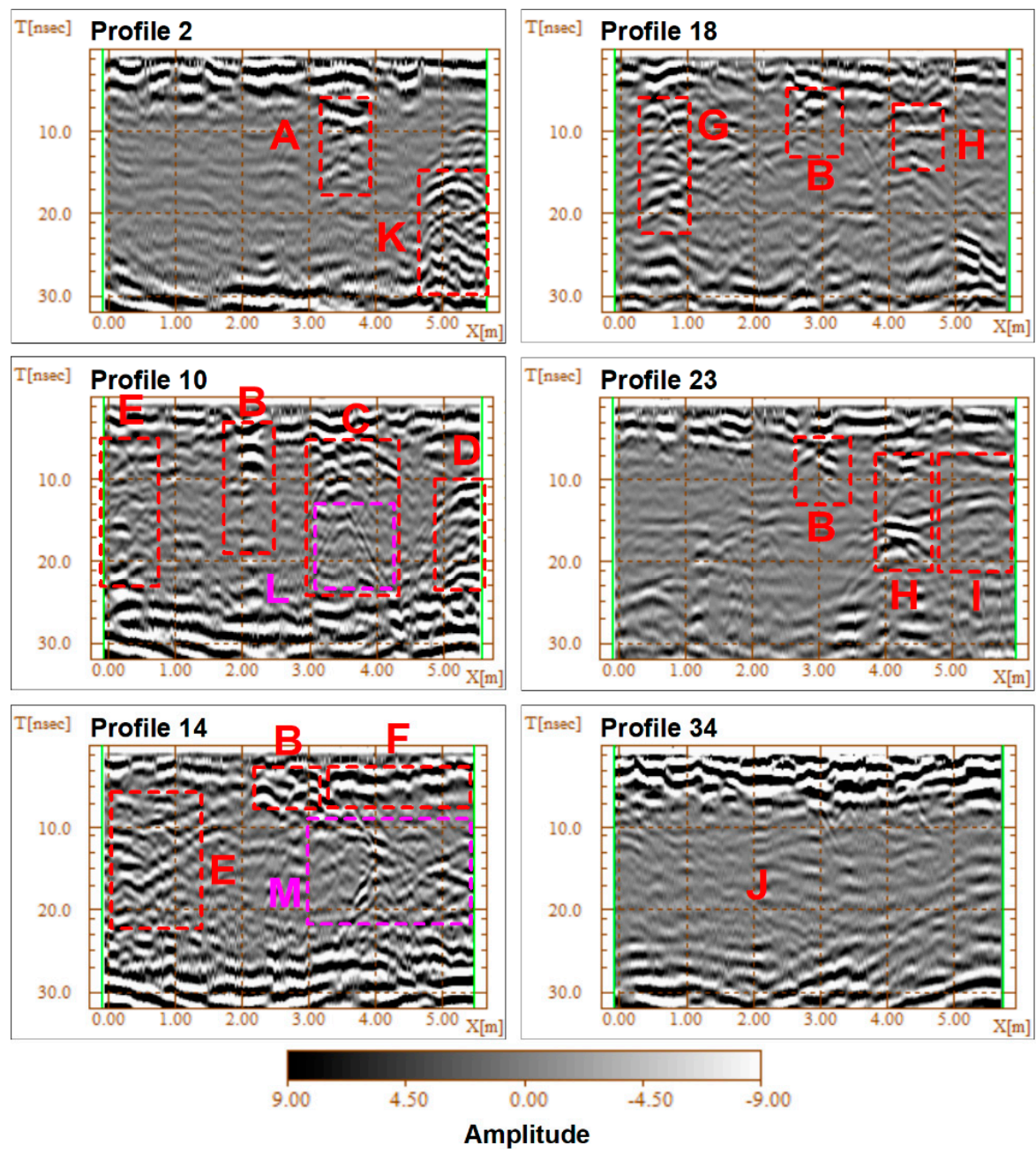

Figure 5. Indication of anomalies on selected transversal radargrams from the entire data set relative to the frequency of $600 \mathrm{MHz}$.

Then, time slices for time windows equal to $8 \mathrm{~ns}$ with an overlap 3 ns were processed, considering the overall data set of averaged squared amplitudes of the return reflection for the frequency of $600 \mathrm{MHz}$. The creation of maps was realized using the inverse distance option interpolating all data within a searching and blanking radius of $0.75 \mathrm{~m}$, a smoothing factor of two, and a grid cell size of $0.02 \mathrm{~m}$.

\section{Results}

Figures 5 and 6 report some selected, processed radargrams, respectively, longitudinal and transversal to the main side of the church. A first layer was evident in both transversal and longitudinal sections in the range $0-5 \mathrm{~ns}$ that is probably due to the construction materials of the actual pavement 
(facing stones and leveling screed). Furthermore, in all radargrams, a strong reflection was displayed at about $28 \mathrm{~ns}$ that can be associated with the presence of a rocky layer. Between them, in the range 8-28 ns, different anomalies were highlighted in a quite uniform matrix. Most of them were located in the temporal window of 5-16 ns, and we could distinguish punctual targets (such as anomalies A-K in transversal profiles) and sub-horizontal features (such as B anomaly in longitudinal profiles). Some anomalies extended until deeper strata, such as D, E, F, H, I, and K in profiles 2, 14, and 23. Weaker reflections ( $\mathrm{L}$ and $\mathrm{M}$, marked with magenta color) were also highlighted in the range 10-20 ns. Profiles 27-35 put in evidence in the range 5-28 anomalies of small entities with respect to the other profiles, as shown, for example, in profile 34 in Figure 5 (marked with J).
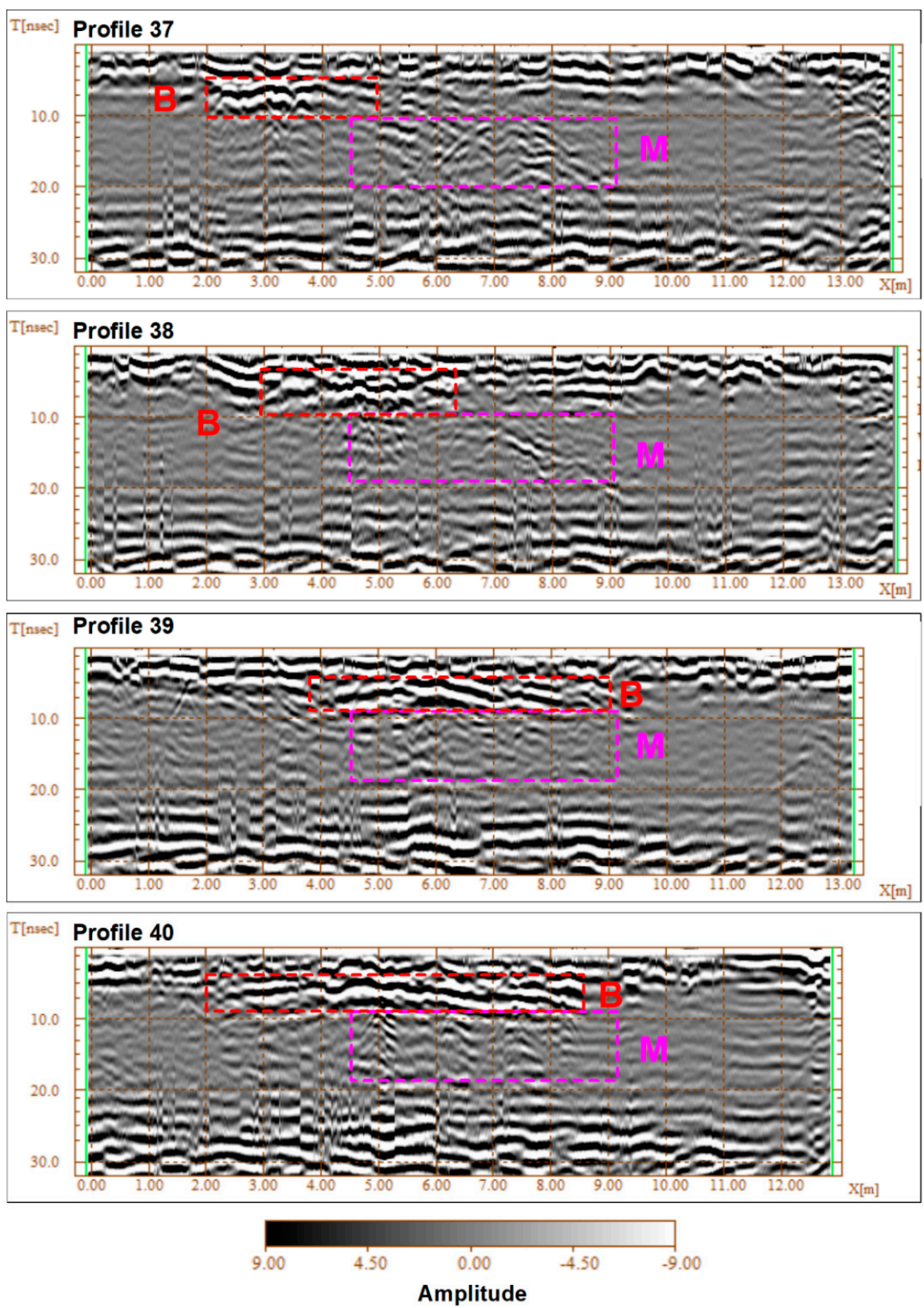

Figure 6. Indication of anomalies on selected longitudinal radargrams from the entire data set relative to the frequency of $600 \mathrm{MHz}$.

Figure 7 displays the modeled time slices relative to growing ranges in the temporal scale overlapped to the actual planimetry of the church. The maps highlight a complex overlapping of 
maxima of amplitudes of the electromagnetic signal with a regular pattern. The more superficial slices allowed imagining the presence of different septa of walls arranged following two orientations, one related to the oblique wall of the monastery in the northwestern side of the church and one in accordance with the perimeter of the church. In deeper slices, a distribution of maxima of amplitude with a rectangular shape, oriented as the church, persisted.

In Figure 8, anomalies individuated on the radargams were evidenced on the horizontal slices relative to 8-16 ns and 11-19 ns. Lines of interpretation help to delineate a hidden archaeological structure in which there is probably overlapping of walls of different construction phases.

In the time slice relative to 8-16 ns (Figure $8 \mathrm{a}$ ), the highs $\mathrm{B}, \mathrm{E}, \mathrm{G}$, and $\mathrm{H}$ were parallel and seemed to be connected with I anomaly, that was the clear projection of the northwestern oblique wall. The parallel highs D, C, and F were perpendicular to B, E, G, and H. Furthermore, C and F had the same dimensions $(1.5 \mathrm{~m} \times 0.5 \mathrm{~m})$ and were spaced half meter each other. In the area marked with $\mathrm{J}$, medium and low values of amplitude were detected.

In the time slice relative to 11-19 ns, the orientation of anomalies changed, and different regular patterns may be distinguished. While A, K, D, H, I, E, and G anomalies persisted, in correspondence of B, C, and F anomalies displayed in Figure 8a, week dishomogeneities (B, L, and M in Figure 8b) occur. Even if of a minor entity with respect to the shallow ones, their rectangular shape in accordance with persisting ones let us report $\mathrm{L}$ and $\mathrm{M}$ as probable buried targets.
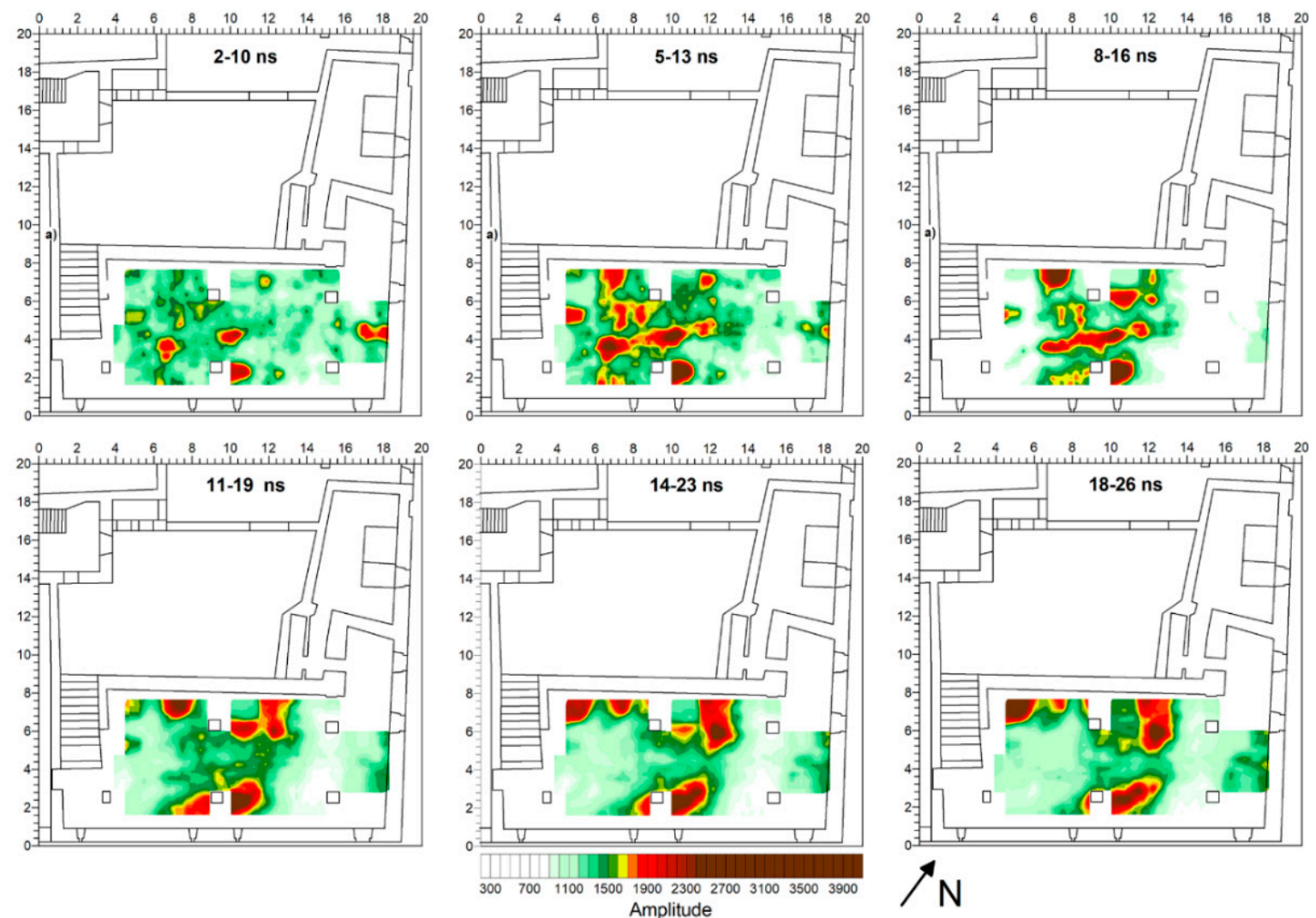

Figure 7. Time slices in the range $0-26 \mathrm{~ns}$, distances in meters relative to the frequency of $600 \mathrm{MHz}$. 


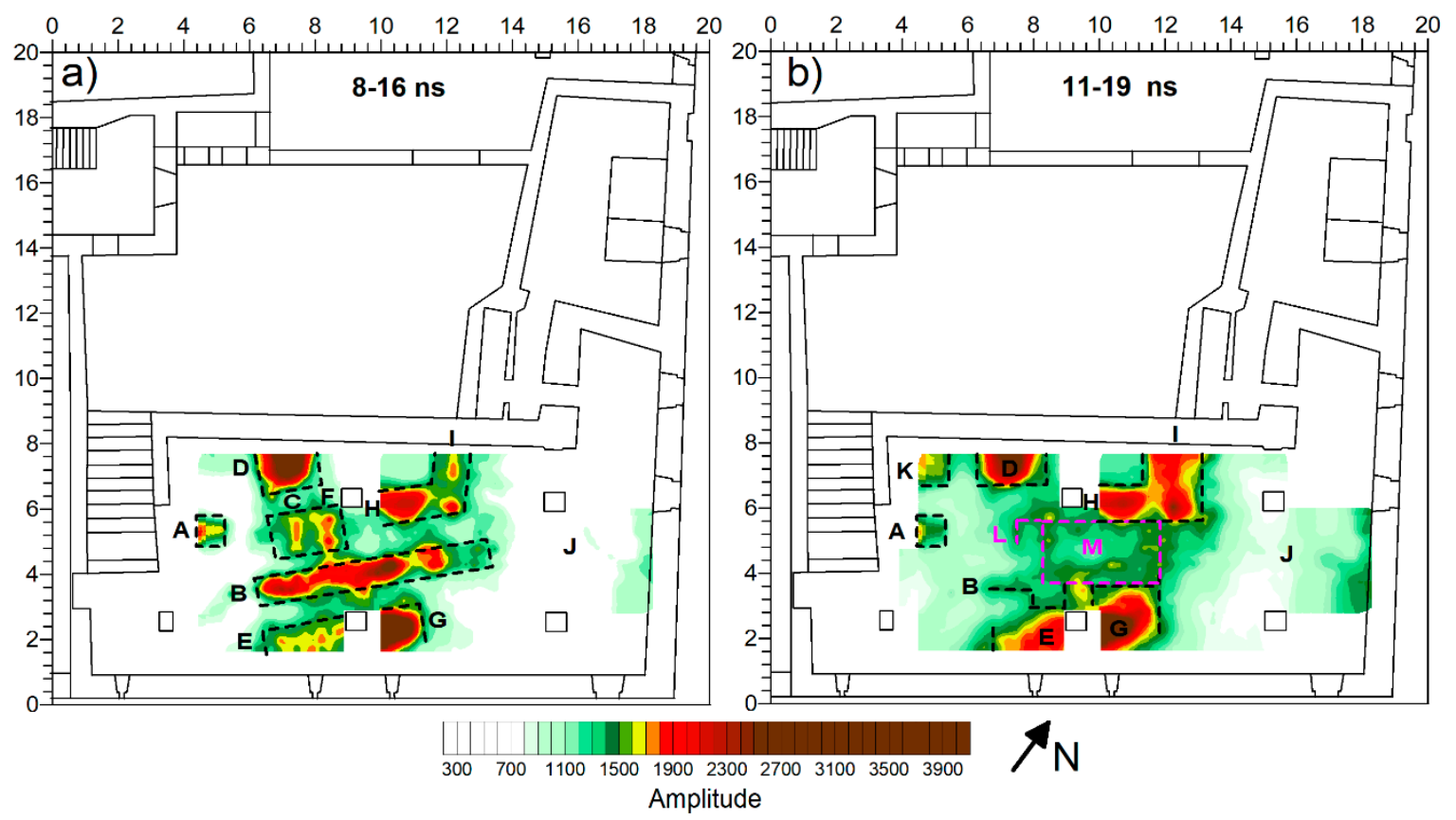

Figure 8. Time slices relative to the time windows 8-16 ns (a) and 11-19 ns (b) with an interpretation of anomalies. Distances in meters.

\section{Discussion and Conclusions}

GPR investigations conducted in the small underground chapel of Saint Cosma in Helerito seemed to attest to the presence of structural schedules referring to various chronological moments.

The analysis of each 2D radargram led to the identification of two kinds of anomalies: punctual anomalies or hyperbolas imputable to linear targets with different thickness intercepted transversely, and horizontal anomalies attributable to the same kind of buried features scanned along their entire length directly from the top surface. The relative horizontal position and the spatial distribution of the underlying targets were more appreciable in the horizontal maps relative to different portions of the investigated soil. The indication of the reflections in the radargrams with their corresponding anomalies in the time slices in comparison with the actual wall structures provided a detailed and clear analysis of the data that helped in a correct interpretation of the results from the archaeological point of view.

The main consideration that can be derived from this research is that the anomalies recorded in the most representative time intervals (8-16 ns and 11-19 ns) revealed the presence of at least two structural alignments that follow two distinct, well-defined orientations in geometry.

The first set of anomalies (detected in the time range 8-16 ns), probably related to a recent single design moment, indicates a shallow structure oriented approximately NNE-SSO that differs in orientation both from the perimeter of the modern church and from the distribution of the internal spaces (Figure 8a). In particular, the I anomaly is clearly the projection into the soil of the actual northwestern oblique wall and links this group of anomalies to the modern building. Furthermore, the parallel E-G, B and $\mathrm{H}$ anomalies and the ones perpendicular to them $(\mathrm{D}, \mathrm{C}$, and $\mathrm{F})$ due to the regularity of their geometry allow imagining the septa of walls belonging to the same building characterized by very small rooms and environments similar to others existing in the modern building. The analogy with the walls of the Monastery of Saints Cosma and Damiano, lead to the supposition that the superficial anomalies belong to the recent structure of the medieval period whose organization has evidently been distorted in more recent times in variations related to the Church of Saint Cosma in Helerito. 
The second group of anomalies, on the other hand, is the one indicated in the deeper maps (in particular in the time slice relative to 11-19 ns, shown in Figure $8 \mathrm{~b}$ ). They probably refer to an older phase of the complex, arranged along a NE-SO axis, and their orientation matches the upper monastery complex. The type of structure identified has the characteristic of having a central room located in the center of the nave of the current Church of Saint Cosma in Helerito (M rectangular space) supported on the sides by significant anomalies (E-G, H-I, and D). Furthermore, small spaces surrounded by fragmented anomalies are also imaginable ( $\mathrm{L}$, for example). Even if $\mathrm{M}$ and $\mathrm{L}$ anomalies appear to be weaker with respect to the other strong ones, their attribution to hyperbola tails or other aspects of radar reflections of the upper B anomaly (Figure 8a) can be excluded as it clearly has a different orientation. Rather, a link with the second group of anomalies identified (E-G, H-I, and D in Figure 8b) can be hypothesized.

Having intercepted the rocky layer at about $28 \mathrm{~ns}$, this structure could be associated with the oldest construction phase, perhaps incised in the bedrock, such as the numerous cave chapels that, starting from at least the late ancient period (V century A.D.) but even more from the early Middle Ages (VI-IX centuries A.D.), populated the national territory. This type of construction was built indiscriminately from north to south of the country and the hypothesis of an analogous chapel that may refer to the chapel of Saint Cosma in Sylvis, still not intercepted today by direct archaeological investigations, is very suggestive. Moreover, there are numerous scholars, from Gattola to Guerra, who hypothesize the presence in the area of a Basilian cell built in the V century A.D. as a shelter for travelers, and perhaps confirmed by some elements of reuse, preserved in the church and the monastery, referable to the same era.

The overlapping of the two different groups of supposed targets occurs in a very restricted portion of the soil. This is proved, for instance, by the analysis of the angle that separates the I and $\mathrm{H}$ anomalies: While, in the more superficial slice relative to $8-16 \mathrm{~ns}$, it is slightly wider than 90 degrees, in the deeper slices, it is perfectly right, changing path in the bottom layers. This leads us to suppose the coexistence of two very close but different constructions, stratified in the same point, confirming GPR's great ability to discern, with high resolution, a complex buried with an overlay of archaeological features in a very narrow soil thickness.

Future further field campaigns of prospection will also be planned using other types of antennas with higher frequencies to obtain a better resolution and to integrate/correlate the results with other methods, such as the electrical resistivity tomography.

In general, the achieved geophysical results proved the efficiency of the adopted methods, adding scientific value to the status of knowledge of the case study through a fast and non-invasive survey, able to guide direct investigations in a targeted and precise manner. A direct verification in the field will give certainty of the nature of the buried objects and, in the case of ancient finds, will define their age and the real archaeological value of the anomalies found.

Author Contributions: Conceptualization, E.D.G., N.P., P.M.; Investigation, E.D.G., N.P.; Data Curation, M.C., V.G., N.P.; Writing-Original Draft Preparation, M.C., N.P., P.M.; Writing-Review and Editing, M.C., P.M.; Supervision, P.M.; Project Administration, P.M. All authors have read and agreed to the published version of the manuscript.

Funding: This research received no external funding.

Acknowledgments: Special thanks to Franco Salvatori and Pierluigi Magistri of the University of Rome "Tor Vergata", who suggested the investigation and the Abbess of the Monastery, R.M. Donatella di Marzio, who made it possible.

Conflicts of Interest: The authors declare no conflict of interest.

\section{References}

1. Cozzolino, M.; Di Giovanni, E.; Mauriello, P.; Piro, S.; Zamuner, D. Geophysical Methods for Cultural Heritage Management; Springer Geophysics Series; Springer: Cham, Switzerland, 2018. 
2. Schmidt, A.; Linford, P.; Lindford, N.; Gaffney, C.; David, A. (Eds.) EAC Guidelines for the Use of Geophysics in Archaeology; Archaeolingua Press: Budapest, Hungary, 2015.

3. Compare, V.; Cozzolino, M.; Di Giovanni, E.; Mauriello, P. Examples of resistivity tomography for cultural heritage management. In Near Surface 2010 - 16th European Meeting of Environmental and Engineering Geophysics; European Association of Geoscientists and Engineers, EAGE: Houten, The Netherlands, 2010. [CrossRef]

4. Cozzolino, M.; Di Giovanni, E.; Mauriello, P.; Vanni Desideri, A.; Patella, D. Resistivity tomography in the Park of Pratolino at Vaglia (Florence, Italy). Archaeol. Prospect. 2012, 19, 253-260. [CrossRef]

5. Minelli, A.; Cozzolino, M.; Di Nucci, A.; Guglielmi, S.; Giannantonio, M.; D’Amore, D.; Pittoni, E.; Groot, A.M. The prehistory of the Colombian territory: The results of the Italian archaeological investigation on the Checua site (Municipality of Nemocòn, Cundinamarca Department). J. Biol. Res. 2012, 85, 94-97. [CrossRef]

6. Osella, A.; Grunhut, V.; Martinelli, H.P.; de la Vega, M.; Bonomo, N. ERT for localizing 17th century tunnels at a Jesuit Mission in Buenos Aires, Argentina. In Near Surface Geoscience 2013-19th EAGE European Meeting of Environmental and Engineering Geophysics; European Association of Geoscientists and Engineers, EAGE: Houten, The Netherlands, 2013.

7. Cozzolino, M.; Mauriello, P.; Patella, D. Resistivity tomography imaging of the substratum of the bedestan monumental complex at Nicosia, Cyprus. Archaeometry 2014, 56, 331-350. [CrossRef]

8. Al-Saadi, O.S.; Schmidt, V.; Becken, M.; Fritsch, T. Very-high-resolution electrical resistivity imaging of buried foundations of a Roman villa near Nonnweiler, Germany. Archaeol. Prospect. 2018, 25, 209-218. [CrossRef]

9. Tejero-Andrade, A.; Argote-Espino, D.L.; Cifuentes-Nava, G.; Hernández-Quintero, E.; Chávez, R.E.; García-Serrano, A. 'Illuminating' the interior of Kukulkan's Pyramid, Chichén Itzá, Mexico, by means of a non-conventional ERT geophysical survey. J. Archaeol. Sci. 2018, 90, 1-11. [CrossRef]

10. Obrocki, L.; Eder, B.; Gehrke, H.J.; Lang, F.; Vött, A.; Willershäuser, T.; Rusch, K.; Wilken, D.; Hatzi-Spiliopoulou, G.; Kolia, E.-I.; et al. Detection and localization of chamber tombs in the environs of ancient Olympia (Peloponnese, Greece) based on a combination of archaeological survey and geophysical prospection. Geoarchaeology 2019, 34, 648-660. [CrossRef]

11. Fischanger, F.; Catanzariti, G.; Comina, C.; Sambuelli, L.; Morelli, G.; Barsuglia, F.; Ellaithy, A.; Porcelli, F. Geophysical anomalies detected by electrical resistivity tomography in the area surrounding Tutankhamun's tomb. J. Cult. Herit. 2019, 36, 63-71. [CrossRef]

12. Cozzolino, M.; Caliò, L.M.; Gentile, V.; Mauriello, P.; Di Meo, A. The Discovery of the Theater of Akragas (Valley of Temples, Agrigento, Italy): An archaeological confirmation of the supposed buried structures from a geophysical survey. Geosciences 2020, 10, 161. [CrossRef]

13. De Smedt, P.; Saey, T.; Lehouck, A.; Stichelbaut, B.; Meerschman, E.; Islam, M.M.; van DeVijver, E.; van Meirvenne, M. Exploring the potential of multi-receiver EMI survey for geoarchaeological prospection: A 90 ha dataset. Geoderma 2013, 199, 30-36. [CrossRef]

14. Simon, F.X.; Tabbach, A.; Sarris, A. Practical assessment of a multi-frequency slingram EMI for archaeological prospection. In CAA2014: 21st Century Archaeology-Concepts, Methods and Tools; Archaeopress Archaeology: Oxford, UK, 2015; pp. 43-49.

15. Lascano, E.; Martinelli, P.; Osella, A. EMI data from an archaeological resistive target revisited. Near Surf. Geophys. 2006, 4, 395-400. [CrossRef]

16. Manfredi, L.I.; Dekayir, A.; Bokbot, Y.; Festuccia, S.; Cozzolino, M.; Gentile, V.; Merola, P.; Repola, L.; Cecalupo, C.; Seghir, M. Integrated multi scale archaeological analysis in Béni Mellal-Khenifra district (Morocco). The case of the fortress of Ighram Aousser. Archeol. Calc. 2020, 31, forthcoming.

17. Mekkawi, M.; Arafa-Hamed, T.; Abdellatif, T. Detailed magnetic survey at Dahshour archeological sites Southwest Cairo, Egypt. NRIAG J. Astron. Geophys. 2013, 2, 175-183. [CrossRef]

18. Fröhlich, N.; Posselt, M.; Schleifer, N. Excavating in a "blind mode". Magnetometer survey, excavation and magnetic susceptibility measurements of a multiperiod site at Bad Homburg, Germany. Archaeol. Pol. 2003, 41, 167-169.

19. Aspinall, A.; Gaffney, C.F.; Schmidt, A. Magnetometry for Archaeologists; Altamira Press: Lanham, MD, USA, 2008.

20. Becker, H. Caesium magnetometry for landscape-archaeology. In Seeing the Unseen-Geophysics and Landscape Archaeology; Campana, S., Piro, S., Eds.; CRC Press Taylor \&Francis Group: Boca Raton, FL, USA, 2009; pp. 129-165.

21. Neubauer, W.; Eder-Hinterleitner, A. 3D-interpretation of post-processed archaeological magnetic prospection data. Archaeol. Prospect. 1997, 4, 191-205. [CrossRef] 
22. Arias, P.; Armesto, J.; Di-Capua, D.; González-Drigo, R.; Lorenzo, H.; Pérez-Gracia, V. Digital photogrammetry, GPR and computational analysis of structural damages in a mediaeval bridge. Eng. Fail. Anal. 2007, 14, 1444-1457. [CrossRef]

23. Ludeno, G.; Cavalagli, N.; Ubertini, F.; Soldovieri, F.; Catapano, I. On the combined use of ground penetrating radar and crack meter sensors for structural monitoring: Application to the historical consoli palace in Gubbio, Italy. Surv. Geophys. 2019, 41, 647-667. [CrossRef]

24. Cozzolino, M.; Gabrielli, R.; Galatà, P.; Gentile, V.; Greco, G.; Scopinaro, E. Combined use of 3D metric surveys and non-invasive geophysical surveys for the determination of the state of conservation of the Stylite Tower (Umm ar-Rasas, Jordan). Ann. Geophys. Italy 2019, 62, 72. [CrossRef]

25. Cozzolino, M.; Di Meo, A.; Gentile, V. The contribution of indirect topographic surveys (photogrammetry and the laser scanner) and GPR investigations in the study of the vulnerability of the Abbey of Santa Maria a Mare, Tremiti Islands (Italy). Ann. Geophys. Italy 2019, 62, 71. [CrossRef]

26. Biscarini, C.; Catapano, I.; Cavalagli, N.; Ludeno, G.; Pepe, F.A.; Ubertini, F. UAV photogrammetry, infrared thermography and GPR for enhancing structural and material degradation evaluation of the Roman masonry bridge of Ponte Lucano in Italy. NDT E Int. 2020, 102287. [CrossRef]

27. Bavusi, M.; Soldovieri, F.; Piscitelli, S.; Loperte, A.; Vallianatos, F.; Soupios, P. Ground penetrating radar and microwave tomography to evaluate the crack and joint geometry in historical buildings: Some examples from Chania, Crete, Greece. Near Surf. Geophys. 2010, 8, 377-387. [CrossRef]

28. Sambuelli, L.; Bhom, G.; Capizzi, P.; Cardarelli, E.; Cosentino, P. Comparison between GPR measurements and ultrasonic tomography with different inversion algorithms: An application to the base of an ancient Egyptian sculpture. J. Geophys. Eng. 2011, 8, 106-116. [CrossRef]

29. Amato, V.; Cozzolino, M.; De Benedittis, G.; Di Paola, G.; Gentile, V.; Giordano, C.; Marino, P.; Rosskopf, C.M.; Valente, E. An integrated quantitative approach to assess the archaeological heritage in highly anthropized areas: The case study of Aesernia (southern Italy). Acta IMECO 2016, 5, 33-43. [CrossRef]

30. Pérez-Gracia, V.; Canas, J.A.; Pujades, L.G.; Clapés, J.; Caselles, O.; Garcia, F.; Osorio, R. GPR survey to confirm the location of ancient structures under the Valencian Cathedral (Spain). J. Appl. Geophys. 2000, 43, 167-174. [CrossRef]

31. Trinks, I.; Karlsson, P.; Biwall, A.; Hinterleitner, A. Mapping the urban subsoil using ground penetrating radar-Challenges and potentials for archaeological prospection. ArcheoSciences 2009, 33, 237-240. [CrossRef]

32. Trinks, I.; Hinterleitner, A.; Neubauer, W.; Nau, E.; Löcker, K.; Wallner, M.; Gabler, M.; Filzwieser, R.; Wilding, J.; Schiel, H.; et al. Large-area high-resolution ground-penetrating radar measurements for archaeological prospection. Archaeol. Prospect. 2018, 25, 171-195. [CrossRef]

33. Cozzolino, M.; Longo, F.; Pizzano, N.; Rizzo, M.L.; Voza, O.; Amato, V.A. Multidisciplinary approach to the study of the temple of Athena in Poseidonia-Paestum (Southern Italy): New geomorphological, geophysical and archaeological data. Geosciences 2019, 9, 324. [CrossRef]

34. Caspari, G.; Sadykov, T.; Blochin, J.; Buess, M.; Nieberle, M.; Balz, T. Integrating remote sensing and geophysics for exploring early nomadic funerary architecture in the Siberian Valley of the Kings. Sensors 2019, 19, 3074. [CrossRef]

35. Conyers, L.B.; Sutton, M.J.; St. Pierre, E. Dissecting and interpreting a three-dimensional ground-penetrating radar dataset: An example from Northern Australia. Sensors 2019, 19, 1239. [CrossRef]

36. Cozzolino, M.; Baković, M.; Borovinić, N.; Galli, G.; Gentile, V.; Jabučanin, M.; Mauriello, P.; Merola, P.; Živanović, M. The contribution of geophysics to the knowledge of the hidden archaeological heritage of Montenegro. Geoscience 2020, 10, 187. [CrossRef]

37. Bianco, C.; De Giorgi, L.; Giannotta, M.T.; Leucci, G.; Meo, F.; Persico, R. The Messapic Site of Muro Leccese: New Results from Integrated Geophysical and Archaeological Surveys. Remote Sens. 2019, 11, 1478. [CrossRef]

38. Cozzolino, M.; Gentile, V.; Giordano, C.; Mauriello, P. Imaging buried archaeological features through Ground Penetrating Radar: The case of the ancient Saepinum (Campobasso, Italy). Geoscience 2020, 10, 225. [CrossRef]

39. Bianchini, M. Edilizia Storica della Marsica Occidentale; Dedalo, R., Ed.; Editrice Dedalo Roma: Roma, Italy, 2011; pp. 99-121.

40. Chronica Monasterii Casinensis, Die Chronik von Montecassino; Hoffmann, H. (Ed.) MGH.SS 34; Hahnsche Buchhandlung: Hannover, Germany, 1980. 
41. Gattola, E. Historia Abbatiae Cassinensis per Saeculorum Seriem Distribuita; Nabu Press: Charleston, SC, USA, 2013.

42. Guerra, A. Tagliacozzo: Momenti di archeologia medieval. In Proceedings of the Tagliacozzo e la Marsica tra XII e XIII secolo. Aspetti di vita Artistica, Civile e Religiosa. Atti del Convegno, Tagliacozzo, Italy, 19 May 2001; pp. 23-44.

43. Colasante, D. Il Taglio nella Roccia. Tagliacozzo e il suo Territorio dal Medioevo al Novecento. Storia di una Comunità dell'Appennino Abruzzese; Villamagna: Tinari, Italy, 2006.

44. Ground Penetrating Radar, Products. Available online: www.idsgeoradar.com (accessed on 13 March 2020).

45. Goodman, D. GPR-SLICE. Ground Penetrating Radar Imaging Software, User's Manual; Geophysical Archaeometry Laboratory: Los Angeles, CA, USA, 2004.

46. Catapano, I.; Gennarelli, G.; Ludeno, G.; Soldovieri, F. Applying ground-penetrating radar and microwave tomography data processing in cultural heritage: State of the art and future trends. IEEE Signal Process. Mag. 2019, 36, 53-61. [CrossRef]

47. Catapano, I.; Gennarelli, G.; Ludeno, G.; Soldovieri, F.; Persico, R. Ground-penetrating radar: Operation principle and data processing. In Wiley Encyclopedia of Electrical and Electronics Engineering; Webster, J.G., Ed.; Wiley: Hoboken, NJ, USA, 2019; pp. 1-23. [CrossRef]

(C) 2020 by the authors. Licensee MDPI, Basel, Switzerland. This article is an open access article distributed under the terms and conditions of the Creative Commons Attribution (CC BY) license (http://creativecommons.org/licenses/by/4.0/). 